\title{
Bone mineral density of rat femurs after hindlimb unloading and different physical rehabilitation programs
}

\author{
Adelton Andrade Barbosa ${ }^{1}$, Ricardo Junqueira Del Carlo ${ }^{*}$, Simone Rezende Galvão ${ }^{3}$ Marcelo José Vilela \\ Mário Jefferson Quirino Louzada ${ }^{5}$, Ana Flora Sousa Brito ${ }^{6}$, Antonio José Natali
}

\begin{abstract}
Bone weakening can occur due to the absence of load on the skeleton or even short periods of decreased physical activity. Therefore, musculoskeletal diseases that involve temporary immobilization by casts, inactivity or tension increases the risk of fractures. Physical activity is the most studied procedure both to prevent damage and to restore bone structure. The present study aimed at evaluating, by bone densitometry on rat femurs, the influence of hindlimb unloading and later running activity on treadmill or free movement. Sixty-four Wistar rats were used, aged 65 days with a mean corporal mass of $316.11 \mathrm{~g}$, randomly divided into eight experimental groups: group 1, the suspended control with seven animals under hindlimb unloading regimen for 28 days, then euthanized; groups 2 and 3, the trained suspended comprising of 7 and five animals, respectively, subjected to hindlimb unloading for 28 days, followed by treadmill exercise for 28 days (group 2) or 56 days (group 3), then euthanized; groups 4 and 5, designated free suspended, comprised of 7 animals each under hindlimb unloading regimen for 28 days followed by free activity in cages for 28 days (group 4) or 56 days (group 5), then euthanized; groups 6, 7 and 8, negative controls, each with 8 animals allowed to free activity in cages and euthanized at the ages of 93, 121 and 149 days, respectively. Bone mineral density (BMD) of the left femur was analyzed by bone densitometry. Unloading by tail-suspension decreased BMD while treadmill training and free activity in cages promoted its recovery in a similar way and over time.
\end{abstract}

Key words: Physical training, physical rehabilitation, bone mineral density.

\section{RESUMO}

\section{Densidade mineral óssea de fêmures de ratos submetidos à hipocinesia dos membros pélvicos e a diferentes programas de reabilitação}

Durante a ausência de carga no esqueleto e mesmo em curtos períodos de atividade física diminuída, pode ocorrer enfraquecimento ósseo. Assim, tratamentos para doenças musculoesqueléticas que envolvam imobilização temporária por meio de talas, repouso forçado ou tração aumentam o risco de fraturas. A atividade física é a medida mais estudada, tanto para evitar danos quanto para promover recuperação da estrutura óssea. O objetivo deste estudo foi avaliar, por meio da densitometria óssea, a influência da hipocinesia e posterior atividade de corrida em esteira ou da movimentação livre, em fêmur de ratos. Foram utilizados 64 ratos Wistar com 65 dias de idade e massa corporal média de 316,11

\footnotetext{
Recebido para publicação em 08/07/2009 e aprovado em 05/07/2011

${ }^{1}$ Physiotherapist, Master of Science. Instituto de Ortopedia e Fisioterapia, Avenida Raul Soares, 49, 2º floor, Centro, 36500-000, Ubá, Minas Gerais, Brazil. adelton.barbosa@ gmail.com ${ }^{2}$ Veterinarian, Doctor. Departamento de Veterinária, Universidade Federal de Viçosa, Avenida Peter Henry Rolfs, s/n, Campus Universitário, 36570-000, Viçosa, Minas Gerais, Brazil. Corresponding author: ricarlo@ufv.br

${ }^{3}$ Veterinarian, Master of Science. Departamento de Veterinária, Universidade Federal de Viçosa, Av. Peter Henry Rolfs, s/n, Campus Universitário, 36570-000, Viçosa, Minas Gerais, Brazil. simone.galvao@ufv.br

${ }^{4}$ In memorian

${ }^{5}$ Electrical Engineer, Ph. Doctor. Faculdade de Odontologia, Universidade Estadual Paulista Júlio de Mesquita Filho, Curso de Medicina Veterinária, Rua Clovis Pestana, 793, Bairro Dona Amélia, 16050-680, Aracatuba, São Paulo, Brazil. louzada@ fmva.unesp.br

${ }^{6}$ Veterinarian. Departamento de Veterinária, Universidade Federal de Viçosa, Avenida Peter Henry Rolfs, s/n, Campus Universitário, 36570-000, Viçosa, Minas Gerais, Brazil. flora_ana@ig.com.br

Bachelor in Physical Education, PhD. Departamento de Educação Física, Universidade Federal de Viçosa, Avenida Peter Henry Rolfs, s/n, Campus Universitário, 36570-000, Viçosa, Minas Gerais, Brazil. anatali@ufv.br
} 
gramas, distribuídos aleatoriamente em oito grupos experimentais: Grupo 1, controle suspenso, constituído de sete animais que permaneceram em regime de hipocinesia dos membros pélvicos por 28 dias e, posteriormente sofreram eutanásia; Grupos 2 e 3, suspensos treinados, compostos por sete e cinco animais respectivamente, que permaneceram em regime de hipocinesia dos membros pélvicos, por 28 dias, e posterior regime de exercício em esteira, por mais 28 dias (grupo 2) e 56 dias (grupo 3) e, posteriormente, sofreram eutanásia; Grupos 4 e 5, suspensos liberados, compostos por sete animais que permaneceram em regime de hipocinesia dos membros pélvicos por 28 dias e, posteriormente, alojados com livre movimentação, em caixa, por 28 dias (grupo 4) e 56 dias (grupo 5) e depois sofreram eutanásia; Grupos 6, 7 e 8, controles negativos, compostos por oito animais, alojados com movimentação livre, em caixa, submetidos à eutanásia com 93, 121 e 149 dias de idade, respectivamente. Foi analisada a densidade mineral óssea do fêmur esquerdo por meio da densitometria óssea. A suspensão pela cauda provocou a diminuição na densidade mineral óssea e, o treinamento em esteira e a atividade livre na caixa, após a suspensão, promoveram a recuperação de forma semelhante e ao longo do tempo.

Palavras-chave: Treinamento físico, reabilitação, densidade mineral óssea.

\section{INTRODUCTION}

Fractures, ligament ruptures, muscle lesions and degenerative or joint diseases may require limb immobilization after surgery or conservative treatment (Appell, 1986, Ocarino et al., 2009).

Such immobilization increases bone resorption and decreases bone formation, resulting in osteopenia, i.e., bone mass decreases in relation to its volume, with simultaneous alterations on material and geometric properties of the bone (Minaire, 1989). Therefore, skeleton unloading even for short periods of diminished physical activity may lead to bone weakening (Maeda et al., 1993).

According to Norman et al. (2000), rats are accepted as experimental models, once differences among their tissues and of other animals are observed; an aspect that imposes some limits to extrapolate results.

Physical training is the most studied countermeasure as treatment and prevention of bone loss and muscle atrophy. Animal studies focusing treadmill training showed increased bone mass and mineral density (Van Der Wiel et al., 1995; Mathey et al., 2002, Ocarino et al., 2009).

According to Hou et al. (1990), exercise effects on the skeleton depend on aspects such as exercise intensity, skeletal maturity, bone type (cortical or trabecular) and anatomical location (diaphysis, metaphysis or epiphysis).

The effect of physical activity on the treatment of osteoporosis also depends on the bone studied (Ocarino et al., 2007) and on the moment that the activity is taken, i.e., before and/or after osteoporosis induction (Ocarino et al., 2009). Physical activity improves bone mass in female rats with castration-induced osteoporosis due to an increase in osteoblast activity, to a connection with osteocytes (Ocarino et al., 2007) and to an increase in osteogenic differentiation of mesenchymal stem cells (Ocarino et al., 2008).

Radiographic densitometry (RD) used to evaluate bone density is reported to be a useful tool for diagnosis and therapeutic guidance for osteometabolic disorders, evaluation of bone fracture repair and other surgical procedures (Louzada, 2001).

The objective of the present study was to evaluate bone mineral density of rat femurs under hindlimb unloading period followed by different rehabilitation periods of time on treadmill or free activity. The analysis of differences between trained (treadmill) and free activities is what differs from our study to previous ones.

\section{MATERIAL AND METHODS}

Methods here presented were reviewed and approved by the Ethics Committee on Animal Research of the Veterinary Department (Universidade Federal de Viçosa, Brazil) according to resolution $n^{\circ} 16 / 2009$ (06/04/2009), in agreement to the rules of the Brazilian College on Animal Experimentation (COBEA).

A total of 64 rats aged 65 days were used. Four animals died during tail-suspension unloading period and 3 were excluded for they didn't adapt to the training protocol. Therefore, the experiment was conducted with 57 animals.

Animals were randomly divided into eight experimental groups: group 1, designated as suspended control, which was comprised of seven animals under hindlimb unloading regimen for 28 days followed by euthanasia; groups 2 and 3, the trained suspended ones, comprising 7 and five animals, respectively, subjected to hindlimb unloading for 28 days, followed by treadmill exercise for 28 days (group 2) or 56 days (group 3), then euthanized; groups 4 and 5, free suspended, with 7 animals on hindlimb 
unloading for 28 days and later housed in cages for free activity for 28 days (group 4) or 56 days (group 5), then euthanized; groups 6, 7 and 8, the negative controls of eight animals each, housed in cages and allowed to free activity, euthanized at the ages of 93, 121 and 149 days, respectively.

Rats were anesthetized (sedation with diazepam (2,5 $\mathrm{mg} / \mathrm{kg}$ / intraperitoneally anesthetized with isoflurane in an anesthetic circuit with $100 \%$ oxygen), the tail was washed with water and detergent and then, completely dried for the application of tincture of benzoin on the entire skin. Next, the tail was wrapped in adhesive foam beginning at the base of the tail above the hair line up to two thirds proximally and then, entirely covered by an elastic bandage. Covering the elastic bandage, a traction strip was applied forming a loop that secured the animal to the suspension system with a swivel. The procedure was followed by the amputation of the distal third of the tail, not covered by the system, to prevent necrosis.

The suspension system was adapted to two stands with three shelves each. Eight animals were elevated on each shelf with limited space for movements. The stand structure allowed forelimb movement, supported on the shelf bottom, although, with hindlimbs elevated (Figure 1). Only animals in groups 1 through 5 were suspended by the tail, what took place immediately after anesthesia recovery.

On the shelve's bottom, shavings were placed and hygiene done daily. In such system, animals were allowed free access to water and food.

Animals in groups 6, 7 and 8 were housed in polypropylene cages for rats, dimensions of 49 x 34 x 16 $\mathrm{cm}$, with no scheduled physical activity, only free deambulation.

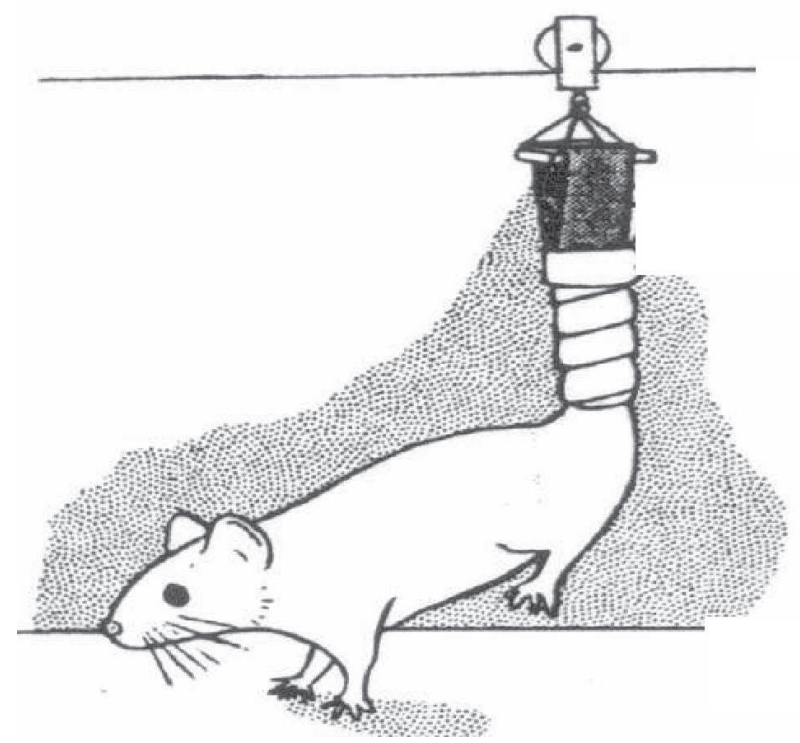

Figure 1. Details of rat's tail suspension model of hindlimb unloading in experimental groups 1 through 5 .
Animals in groups 2 and 3 were trained to walk on a motorized treadmill (Insight, model EP-131), composed of six individual hutches, with $15 \mathrm{~cm}$ in height, internal width of $10 \mathrm{~cm}$ and $50 \mathrm{~cm}$ in length.

The protocol for physical training was conducted according to methods described by Veras-Silva et al. (1997) with minor changes. Training began on the day following release from the restrain system. Animals ran 10 minutes a day, with a 5-minute increase each day, until reaching a daily 60-minutes training, first at $10 \mathrm{~m} /$ min. Such gradual increase in training time allowed the animals adaptation. Treadmill speed was increased to $14 \mathrm{~m} / \mathrm{min}$ from by third week on, always on a horizontal position, what characterizes a low-intensity exercise. Group 2 remained under such protocol for 28 days and group 3 for 56 days. Each week, animals were trained for five consecutive days and allowed to rest for twodays.

Corporal mass of each animal was measured before and after the experimental period using analytical balance (Helmac ${ }^{\circledR}$, model HM 1000, 0.01g).

At the end of each experimental period the animals were euthanized in $\mathrm{CO}_{2}$ chambers. Femurs were collected, cleaned of soft tissue, identified, enclosed in gauze embedded in saline and preserved in $-20^{\circ} \mathrm{C}$ freezer. Carcasses were incinerated.

For densitometry, bones were thawed first in a refrigerator $\left(3 \mathrm{a} 5^{\circ} \mathrm{C}\right)$ for 24 hours and at room temperature until temperature equilibrium, when they were analyzed.

Bone mineral density (BMD), in $\mathrm{g} / \mathrm{cm}^{2}$, was given by the bone mineral content (BMC), all left femurs measured using an energy $\mathrm{X}$ ray absorptiometry (DPX-ALPHA model), with a special software for rats.

Data was tested for normality (Kolmogorov-Smirnov test) and then analyzed using analysis of variance (oneway ANOVA for time and exercise time and its control), Student t-test for analyzes of two independent groups (suspension and exercise) and Pearson correlation test to determine variable relations. For post hoc multiple variation analysis, Tukey test was used for parametric analyzes and Dunn's test for non-parametric ones. Data analysis was performed using the statistical software SigmaStat version 3.0 (SPSS); P values of $<0.05$ were considered significant.

\section{RESULTS AND DISCUSSION}

Bone mass decrease, occurred during unloading period, can increase the risk of fractures when normal physical activity is re-initiated. Due to imprecise measurement technique, bone mass loss measure is not quantitatively trustful or understood in some cases (Cavanagh et al., 2005).

Rev. Ceres, Viçosa, v. 58, n.4, p. 407-412, jul/ago, 2011 
Data from the present study may be useful to establish actions for the prevention or treatment of osteopenia, osteoporosis or even for those under long immobilization or bed rest periods of time. Furthermore, these data may help to establish proper therapeutic rehabilitation programs for bone weakening due to inactivity.

The rat was chosen as the animal model, since they are easily maintained in the laboratory, they are of a lowcost maintenance and mostly for the possibility to simulate unloading. Furthermore, according to Norman et al. (2000), they are accepted as models for such studies, regarding differences from tissues of other animals.

For final results, only animals with no problems during the experimental period were considered. Tail rupture during suspension was observed in one animal of each of groups 1, 2, 4 and 5, and 3 animals in group 3 did not adapt to training protocol.

Treadmill training is an extensively studied physical exercise to restore the structure of the musculoskeletal system (Van Der Wiel et al., 1995; Kaneps et al., 1997; Norman et al., 2000). Rats adaptation to such exercise training model was difficult in the present study, resulting on the need to exclude some of them.

Different protocols on treadmill exercise have been studied; for the present one, the protocol described by Veras-Silva et al. (1997) was used with few modifications, characterizing low-intensity exercise. Such protocol is recommended since the animals experience muscle mass loss and alterations on bone structure due to the hindlimb unloading period, what contraindicate moderate or highintensity activity.

Norman et al. (2000) showed that training for 15 days promoted only body mass recovery while the present work showed not only recovery but increase in the body mass, what can be explained by longer unloading and training periods of time.

On the results here presented it is noteworthy that both treadmill exercise and free activity could have stimulated muscle mass recovery (Table 1 ) and bone mineral intensity (Figure 2), showing as a practical result that in these circumstances, a stronger and more resistant musculoskeletal complex was obtained.

Analyzing unloading effects (G1, G4 and G5) in comparison to their respective control groups (G6, G7 and G8), significant differences on bone mineral density (BMD) were observed for groups G1 x G6 ( $\mathrm{p}=0.009$, Mann-Whitney test) and G4 x G7 ( $p=0.014$, Student t test), while G5 x G8 did not differ significantly ( $p=0.181$, Student $t$ test), i.e., unloading for 28 days was sufficient to decrease bone density. According to Frateschi (2002), the relation resorption versus bone formation is altered during unloading period, resulting in diminished bone mass.
On the other hand, on such comparison of G5 x G8, i.e., animals under unloading protocol for 4 weeks and later allowed free activity in the cage for eight weeks, results can be considered favorable, since they recovered bone mineral density to the levels of the control group (Figure 2).

At the beginning of the immobilization period, decreased loading results on diminished bone formation but bone resorption is left temporarily with no opposing activity (Cornwall, 1984). It is estimated that approximately $30 \%$ of the entire bone loss induced by experimental immobilization of rats is caused by an increase in bone resorption and $70 \%$ by diminished formation (Minaire, 1989).

A significant difference was observed in the comparison of the unloading group with later free activity for 4 weeks (G4) to its control (G7), what shows that free activity in the cage for 28 days after the same unloading period of time was not enough to restore bone mineral density to control levels (Figure 2), in agreement with work by Trebacz (2001).

On the other hand, on such comparison of G5 x G8, results were different, i.e., animals under unloading protocol for 4 weeks and later allowed free activity in the cage for eight weeks, did recover bone mineral density to the levels of the control group (Figure 2).

Analyzing the effect of the treadmill activity period (G2 and G3) and suspended control group (G1), by the following comparisons $\mathrm{G} 3$ x G2, G3 x G1 e G2 x G1 using Tukey test, only G3 x G2 did not show a significant difference ( $p=0.073, p=0.001$ and $p=0.001$, respectively).

Similarly, analyzing the effect of the treadmill activity period (G4 and G5) and suspended control group (G1), the following comparisons were made using Tukey test

Table 1. Mean values and standard deviation of body mass at the beginning and end of the experiment for the 8 experimental groups, subjected (groups 1 to 5) or not (groups 6 to 8 ) to hindlimb unloading

\begin{tabular}{lccc}
\hline \multirow{2}{*}{ Groups } & Initial body mass $(\boldsymbol{g})$ & Final body mass $(\boldsymbol{g})$ \\
\cline { 2 - 4 } & $\boldsymbol{M} \pm \boldsymbol{D P}$ & $\boldsymbol{M} \quad \mathbf{D} \boldsymbol{P}$ \\
\hline 1 & $327.0 \pm 30.6$ & $295.8 \pm 24.3 \mathrm{a}$ \\
2 & $318.9 \pm 23.8$ & $362.7 \pm 29.9 \mathrm{~b} \mathrm{c}$ \\
3 & $315.2 \pm 29.1$ & $432.6 \pm 44.4 \mathrm{~b}$ \\
4 & $323.4 \pm 12.5$ & $391.8 \pm 21.2 \mathrm{~b}$ \\
5 & $313.7 \pm 25.5$ & $414.1 \pm 50.0 \mathrm{~b}$ \\
6 & $317.8 \pm 27.9$ & $373.0 \pm 26.7$ & \\
7 & $313.9 \pm 31.8$ & $423.6 \pm 33.0 \quad \mathrm{c}$ \\
8 & $299.0 \pm 37.5$ & $472.7 \pm 39.9$ & \\
\hline
\end{tabular}

$\mathrm{P}<0.05$ (Teste Tukey); b vs G1; a vs G6; c vs G4

Group 1, suspended control; Groups 2 and 3, trained suspended; Groups 4 and 5, free suspended and; Groups 6, 7 and 8, negative controls. 


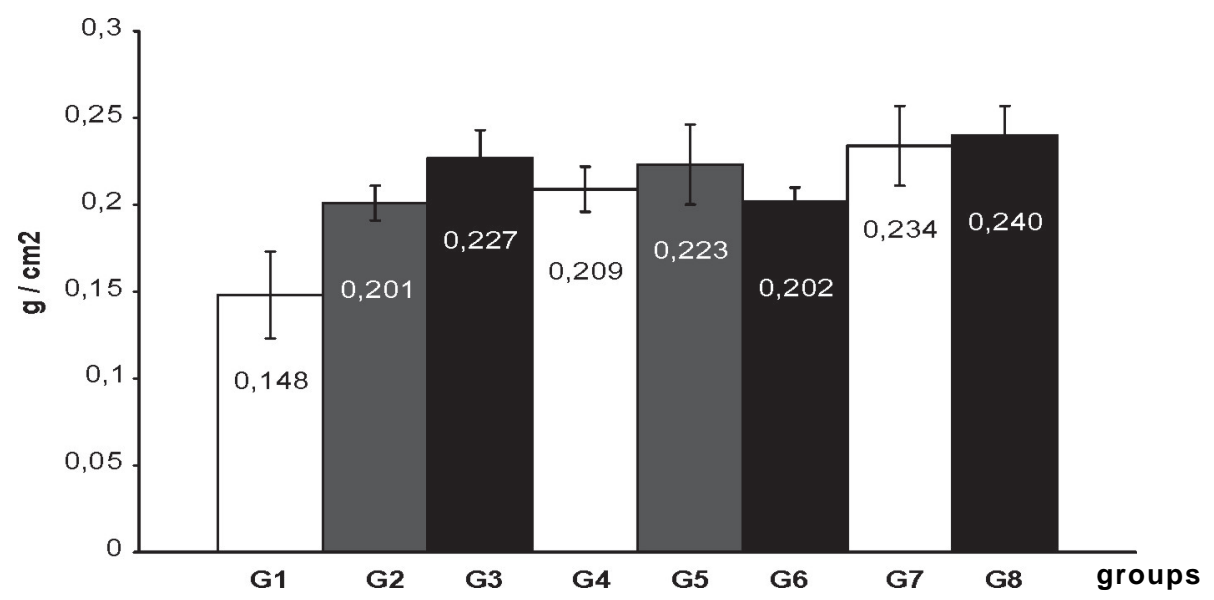

Figure 2. Mean and standard deviation of bone mineral density of the left femur of rats from the 8 experimental groups. Group 1, suspended control; Groups 2 and 3, trained suspended; Groups 4 and 5, free suspended and; Groups 6, 7 and 8, negative controls.

G5 x G1, G4 x G1 e G5 x G4. Both G5 x G1 and G4 x G1 showed differences for BMD $(\mathrm{p}=0.001)$ (Figure 2), while G5 x G4 were not different ( $p=0.473)$.

Hindlimb unloading induced the decrease on BMD, restored by treadmill training and free activity in the cage, although their BMD did not reach values of the control group (G8), which comprised animals of the same age that did not undergo the unloading protocol.

Data shows that both activities were capable of restoring BMD in the beginning (4 weeks), but no significant results were observed on the following timepoints since BMD were similar to the control group (G8). It must also be considered that time needed for the entire recovery is greater than the one necessary to induce the osteogenic changes in bone (Kannus et al.,1994).

Tukey test was used to compare control groups (G6, G7 e G8), analyzing the effect of time. Significant differences were observed for G8 x G6 and G7 x G6, p=0.003, but no difference was fond for G8 x G7 ( $p=0.993)$. These results (Figure 2) probably express bone tissue maturation with time which tended to stabilize at 121 days.

Comparison between treadmill training (G2 and G3) and free activity in a cage (G4 and G5) were done using Student $\mathrm{t}$ test. No significant difference was found when comparing G2 x G4 and G3 x G5 ( $\mathrm{p}=0.257$ and $\mathrm{p}=0.312$, respectively). It can be noted that no benefit resulted from the running training of low intensity in relation to free activity. Greater efficiency of such a physical training was expected in comparison to free activity in a cage, although, both treatments showed similar partial recovery in relation to control at 149 days of age (G8). It can be inferred that the longer duration and greater intensity of treadmill physical activity could positively affect BMD since bone could be under greater load and, consequently, greater deposition of bone tissue would occur according to Yeh et al. (1993) and Kaneps et al.
(1997). Nevertheless, Norman et al. (2000) reported, using the same experimental model of investigation, a significant greater BMD of femurs of rats after treadmill training in comparison to untrained ones. Such observation is probably a result of different unload and rehabilitation protocol periods.

The results here presented also point that even non scheduled physical activity is capable of restoring bone mass after loss by immobilization periods and that rehabilitation programs can be established independently of expensive equipment.

\section{CONCLUSIONS}

Under the conditions of the present work, it can be concluded that tail-suspension reduces bone mineral density of the femur of rats subjected to a hindlimb unloading protocol. Furthermore, treadmill training and physical activity restore bone mineral density in a similar way and over time.

\section{ACKNOWLEDGEMENTS}

The authors thank CNPq and FAPEMIG for financial support.

\section{REFERENCES}

Appell HJ (1986) Skeletal muscle atrophy during immobilization. International Journal Sports Medicine, 7:1-5.

Cavanagh PR, Licata AA \& Rice AJ (2005) Exercise and pharmacological countermeasures for bone loss during longduration space flight. Gravitational Space Biological Bulletin, 18:39-58.

Cornwall M (1984) Biomechanics of noncontractile tissue. A review. Physical Terapy, 63:1869-1873.

Frateschi MEBJM (2002) Efeitos da imobilização e remobilização em algumas propriedades mecânicas do osso. Dissertação de Mestrado. Universidade de São Paulo, São Paulo. 59p. 
Hou JCH, Salem GJ, Zernicke RF \& Barnard RJ (1990) Structural and mechanical adaptations of immature trabecular bone to strenuous exercise. Journal Applied Physiology, 69:1309-1314.

Kaneps AJ, Stover SM \& Lane NE (1997) Changes in canine cortical and cancellous bone mechanical properties following immobilization and remobilization with exercise. Bone, 21:419423.

Kannus P, Josza L, Renstrom P, Jarvinen M, Kvist M, Vieno T, Jarvinent HA \& Natria A (1994) Free mobilization and low- to high-intensity exercise in immobilization- induced muscle atrophy. Journal Applied Physiology, 84:1418-1424.

Louzada MQ J (2001) Densitometria óptica radiográfica em análise de densidade óssea de mandíbula de coelhos castrados. Revista Faculdade Ondontologia, 13:33-38.

Maeda H, Kimmel DB, Raab DM \& Lane NE (1993) Musculoskeletal recovery following hindlimb immobilization in adult female rats. Bone, 14:153-159.

Mathey J, Horcajada-Molteni MN, Chanteranne B, Picherit C, Puel C, Lebecque P, Cubizoles C, Davicco M J, Coxam V \& Barlet JP (2002) Bone mass in obese diabetic Zucker rats: influence of treadmill running. Calcified Tissue International, 70:305-311.

Minaire P (1989) Immobilization osteoporosis. A review. Clinical Rheumatology, 8:95-103.

Norman TL, Bradley-Popovich G, Clovis N, Cutlip G \& Bryner RW (2000) Aerobic Exercise as a countermeasure for microgravity-induced bone loss and muscle atrophy in a rat hindlimb suspension model. Aviation Space Evironmental Medicine, 71:593-598.
Ocarino NM, Marubayashi U, Cardoso TGS, Guimarães CV, Silva AE, Torres RCS \& Serakides R (2007) Physical activity in osteopenia treatment improved the mass of bones directly or indirectly submitted to mechanical impact. Journal Musculoskeletal and Neuronal Interactions, 7:84-93.

Ocarino NM, Boeloni JN, Goes AM, Silva JF, Marubayashi U \& Serakides R (2008) Osteogenic differentiation of mesenchymal stem cells from osteopenic rats subjected to physical activity with and without nitric oxide synthase inhibition. Nitric Oxide. Biology and Chemistry, 19:320-325.

Ocarino NM, Silva JF, Santiago L, Rocha C, Marubayashi U \& Serakides R (2009) Treadmill training before and/or after ovariectomy is more effective in preventing osteopenia in adult female rats. Science \& Sports, 24:52-55.

Trebacz H (2001) Disuse-induced deterioration of bone strength is not stopped free remobilization in young adult rats. Journal Biomechanics, 34:1631-1636.

Van Der Wiel HE, Lips P, Graafmans, WC, Danielsen CC, Nauta J \& Van Lingen A (1995) Additional weight-bearing during exercise is more important than duration of exercise for anabolic stimulus of bone: a study of running exercise in female rats. Bone, 16:73-80.

Veras-Silva AC, Mattos KC, Gava NS, Brum PC, Negrão CD \& Krieger EM (1997) Low-intensity exercise training decreases cardiac output and hypertension in spontaneously hypertensive rats. American Journal Physiology, 273:627-631.

Yeh JK (1993) Effect of treadmill exercise on vertebral and tibial bone mineral content and bone mineral density in the aged adult rat: Determined by dual energy X-ray absorptiometry. Calcified Tissue International, 52:234-238. 